ACEVEDO, AKOS; MEDEIROS, AM; BARROSO, PA; COSTA, GN; LOPES, ACA; GOMES, RLF. 2020. Genetic parameters and simultaneous selection using traits of ornamental interest in pepper plants. Horticultura Brasileira 38: 394-399. Doi: http://dx.doi.org/10.1590/s0102-053620200409

\title{
Genetic parameters and simultaneous selection using traits of ornamental interest in pepper plants
}

\author{
Ana Karolina de OS Acevedo ${ }^{1} \mathbb{D}$; Artur M Medeiros ${ }^{1} \mathbb{D}$; Priscila A Barroso ${ }^{1} \mathbb{D}$; Gérson do N Costa ${ }^{1} \mathbb{D}$; Angela \\ CA Lopes ${ }^{1} \mathbb{D}$; Regina Lucia F Gomes ${ }^{1} \mathbb{D}$
}

${ }^{1}$ Universidade Federal do Piauí (UFPI), Teresina-PI, Brasil; anakarolina-sa@hotmail.com; artur.medeiros@ufpi.edu.br; pa.barroso@hotmail. com; gerson.nascimento@live.com; acalopes@ufpi.edu.br; rlfgomes@ufpi.edu.br

\begin{abstract}
Pepper plants of the genus Capsicum are widely grown worldwide. The Capsicum annuum species shows ornamental potential; nevertheless, in the state of Piauí, there has been a lack of studies on its performance, related to quality traits needed to meet market demand. The aim of this study was to estimate the genetic parameters and associations between traits of ornamental interest in $C$. annuum in order to indicate, by simultaneous selection of traits, accessions to start an ornamental pepper breeding program in Piauí. We evaluated 16 accessions of $C$. annuum under plastic house conditions at Universidade Federal do Piauí. Number of days to flowering, number of days to fruit maturation, plant height, number of fruits per plant, fruit persistence, fruit length, fruit width, leaf length and fruit weight were evaluated. A significant difference $(p \leq 0.01)$ between accessions for all traits was noticed. Coefficient of genetic variation / coefficient of experimental variation $[\mathrm{Cvg} / \mathrm{Cve}(\%)]$ ratios were greater than 1 and the genotypic determination coefficient $\left(H^{2}\right)$ values were all greater than $89.95 \%$. The estimates of the genotypic correlations were higher in relation to phenotypic correlations in most of the traits, however, according to path analysis, an effect of residual variable (0.59) was verified. According to the results, the accessions BAGC 98, 199, 207 and 236 can be used as parents to start an ornamental pepper breeding program in Piauí.
\end{abstract}

Keywords: Capsicum annuum, ornamental ideotype, genotypic determination coefficient.

\section{RESUMO}

Parâmetros genéticos e seleção simultânea utilizando caracteres de interesse ornamental em pimenteiras

As pimenteiras do gênero Capsicum são amplamente cultivadas em todo mundo. A espécie Capsicum annuum apresenta potencial ornamental, porém o estado do Piauí ainda carece de estudos sobre o seu desempenho em relação às características de qualidade necessárias para suprir a demanda de mercado. O objetivo desse trabalho foi estimar os parâmetros genéticos e as associações entre os caracteres de interesse ornamental em C. annuum visando indicar, por seleção simultânea de caracteres, acessos para iniciar um programa de Melhoramento de Pimentas Ornamentais no Piauí. Foram avaliados 16 acessos em condições de telado na Universidade Federal do Piauí. Avaliaram-se as características: número de dias para o florescimento, número de dias para maturação de frutos, altura da planta, comprimento da folha, número de frutos por planta, persistência dos frutos, comprimento do fruto, largura do fruto e peso do fruto. Houve diferença significativa $(\mathrm{p} \leq 0,01)$ entre os acessos para todas as características. As razões coeficiente de variação genético e coeficiente de variação experimental $[\mathrm{Cvg} / \mathrm{Cve}(\%)]$ foram superiores a 1 e os valores do coeficiente de determinação genotípico $\left(H^{2}\right)$ foram todos maiores que $89,95 \%$. As estimativas das correlações genotípicas foram superiores em relação às fenotípicas na maioria das características, porém de acordo com a análise de trilha houve efeito da variável residual $(0,59)$. Diante dos resultados, os acessos BAGC 98, 199, 228, 207 e 236, podem ser utilizados como genitores para iniciar um programa de Melhoramento de Pimentas Ornamentais no Piauí.

Palavras-chave: Capsicum annuum, ideótipo ornamental, coeficiente de determinação genotípico.

\section{Received on May 26, 2020; accepted on October 20, 2020}

$\mathrm{P}$ eppers of the genus Capsicum are widely grown all over the world. The fruit is mainly consumed in natura, as dehydrated spice, or as jelly and sauces (Finger \& Pereira, 2016). The species of this genus have gained more and more space in the flower and ornamental plant business (Rêgo \&
Rêgo, 2018), a sector which has grown an average of $10 \%$ per year in Brazil, from 2012 to 2018 (Ibraflor, 2019).

Most pepper plants can be classified as an ornamental potted plant (Rêgo \& Rêgo, 2018). In this market, the plant architecture and number of fruits are the main traits used as quality standard for commercialization. The expected ideotype for ornamental pepper plants includes: (i) harmony between the plant (plant height, canopy width and foliage position) and the pot size, (ii) showy, upright and colorful fruits, with a suitable number for each pot size and (iii) resistance to pests, diseases and 
ethylene (Rêgo \& Rêgo, 2018; Veilling Holambra, 2018).

The genetic diversity of genus Capsicum, considering a small number of ornamental pepper varieties available in the market and registered at Ministry of Agriculture, Livestock and Supply (MAPA), has stimulated the development of pepper breeding programs. Considering the Northeast part of Brazil, the inferior quality of the marketed ornamental pepper plants turns out to be an aggravating factor, due to the distance from the largest potted plant producing center, located in São Paulo (Ibraflor, 2019). The main damages observed in these plants are related to the effect of ethylene released during transport, with an emphasis on the absence of flowers, fruits and leaves (Lima et al., 2017; Ribeiro et al., 2019).

Piauí has several peculiar edaphoclimatic conditions throughout its extensive territory (Andrade Júnior $e t$ al., 2004; Santos et al., 2011). This state is known for its grain production. The example of pepper and other ornamental species breeding programs developed in Paraiba State (Rêgo \& Rêgo, 2016), shows favorable conditions to exploit this new market niche in Piaui State.

Universidade Federal do Piauí has been proposing actions to conduct breeding programs, aiming to strengthen and diversify the production of ornamental plants in the region. These actions are based on new bills, such as Instituição da Política Nacional de Incentivo à Cultura de Flores e de Plantas Ornamentais de Qualidade (Institution of the National Policy to Encourage the Crop of Quality Flowers and Ornamental Plants) newly approved at Comissão de Agricultura e Reforma Agrária (PL 6912-2017) (Agriculture and Agrarian Reform Commission). These actions are based on selecting pepper accessions with ornamental potential; these accessions have been collected (Costa et al., 2019) and stored at the Capsicum Germplasm Bank of the Institution (BAGC/UFPI) (Monteiro et al., 2010).

Searching for new genotypes is facilitated when the correlations between the traits used for selection are already known. Knowing these traits is quite relevant when it is related to late-expressed phenotype, such as number of fruits in pepper plants, or for medium-low heritability variables (Moreira et al., 2018). The correlations show the direction and degree of association between a pair of traits and whether the interrelation is due to genetic factors (pleiotropy or genetic link) or environmental factors (Ramalho et al., 2012). Associated with the trail analysis (Wright, 1921) can also indicate the direct and indirect effects of other variables on the correlation between a pair of traits under study.

Associations between traits are not always favorable. The negative correlation between two traits of economic importance can hinder the selection of genotypes of interest to the breeder. In these cases, geneticstatistical procedures can be applied, such as selection indexes. These indexes allow to obtain simultaneous gains even for traits which have adverse effects, enabling the selection of superior genotypes regardless of the existence or not of correlation (Rangel et al., 2011; Cruz et al., 2012, 2014).

Obtained data will be the base for choosing more appropriate methods to conduct segregating populations, assisting in obtaining and recommending ornamental pepper cultivars for Piauí, as well as to provide information for crop researchers. In this context, the aim of this study was to estimate genetic parameters and associations between traits of ornamental interest in Capsicum annuum in order to suggest, using simultaneous trait selection, accessions to begin an Ornamental Pepper Breeding Program in Piauí.

\section{MATERIAL AND METHODS}

The experiment was carried out in a plastic house, installed in the Department of Phytotechnics, at Centro de Ciências Agrárias da Universidade Federal do Piauí, in Teresina $\left(05^{\circ} 05^{\prime} 05^{\prime} \mathrm{S}, 42^{\circ} 05^{\prime} \mathrm{W}, 73 \mathrm{~m}\right.$ altitude) from February to November, 2017. The local climate is Aw type, tropical climate with dry winter, according to Köppen classification, 1349 mm rainfall distributed from November to May, $27.6^{\circ} \mathrm{C}$ average annual temperature.

We evaluated 16 accessions of Capscium annuum from eight Brazilian states (Table 1). The experiment was conducted in a completely randomized design, with four replicates, considering one plant per plot. Under plastic house conditions ( $50 \%$ shading screen). The accessions were sown in expanded polystyrene trays of 128 cells, filled with the commercial substrate Plantmax ${ }^{\circledR}$. The seedlings showing six to eight definitive leaves were transplanted to polystyrene pots, size 13 , containing soil organic matter/humus substrate at a 2:5 ratio. The seedlings were irrigated daily, on mild sunny hours ( 8 am or $5 \mathrm{pm}$ ), and planting fertilization was done with $2 \mathrm{~g}$ of ammonium sulfate, $17 \mathrm{~g}$ of simple superphosphate and 2.5 $\mathrm{g}$ of potassium chloride, according to recommendation of Alcântara \& Ribeiro (2008) and fertilization, every 30 days after planting, using Nutriverde NPK 13-13-15 fertilizer with micronutrients.

Morpho-agronomic characterization of the accessions was carried out according to the descriptors established by International Plant Genetic Resources Institute (IPGRI, 1995) for genus Capsicum and Ornamental Pepper Classification Criteria of the Veiling Holambra Cooperative, which are quality standards nationally established by Instituto Brasileiro de Floricultura (Ibraflor, 2020).

The authors evaluated number of days for flowering (NDF), which refers to number of days since sowing, up to $50 \%$ of plants showing at least one opened flower; number of days for maturation (NDM), measured since sowing, up to $50 \%$ of plants showing at least one ripe fruit; plant height (ADP), in $\mathrm{cm}$, observed when $50 \%$ of plants showed the first fuits in the beginning of ripening; number of fruits per plant (NFP), according to the average of total number of fruits per accession; fruit persistence (PSF), considering the number of the days when the first ripe fruits appeared up to the last one; Fruit length $(\mathrm{CDF})$, in $\mathrm{mm}$, referring to average length of 10 ripe fruits, taken at random; fruit width (LDF), in $\mathrm{mm}$, measured at the widest point of 10 ripe 
fruits, taken at random; leaf length (CDFol), in $\mathrm{mm}$, which corresponds to the average length of 10 leaves, also taken at random; fruit weight (PDF), referring to the average weight of 10 ripe fruits, taken at random, in grams.

Obtained data were submitted to individual variance analysis. Effects of the accessions were considered fixed. Multicollinearity diagnose was based on the number of condition (NC), considering the ratio between the highest and lowest eigenvalue of the matrix. For $\mathrm{NC}<100$, multicollinearity is considered weak and it does not represent a problem for the analysis; $100 \leq \mathrm{NC} \leq 1000$, multicollinearity is considered moderate to strong and $\mathrm{NC} \geq 1000$ is considered severe (Cruz et al., 2012). When the authors observed moderate to severe multicollinearity, the variables were discarded; this fact contributed to the presence of multicollinearity.

Genotypic and phenotypic correlations were estimated for all trait combinations after multicollinearity diagnosis. The significance of these combinations was estimated using $t$ test with $n^{-2}$ degrees of freedom, in which $n$ corresponds to the number of evaluated genotypes.

Unfolding of correlations into direct and indirect effects was performed using path analysis (Wright, 1921), in which number of fruits per plant ((NFP) was the base variable. This variable was chosen since it is a later variable, and the other traits were considered explanatory variables.

The accessions were classified using genotype-ideotype distance selection indexes (Schwarzach, 1972 cited by Wricke \& Weber, 1986) and the sum of ranking (Mulamba \& Mock, 1978). An equal economic weight was attributed to each evaluated trait. Spearman's correlation coefficient (1904) was used for the correlation between the results of the indexes. All statistical analyses were performed using Genes software (Cruz, 2013).

\section{RESULTS AND DISCUSSION}

A significant difference $(\mathrm{p} \leq 0.01)$ among the accessions for all evaluated traits was verified, showing genetic variability among them. Variability is important for establishing plant breeding programs. An efficient selection of superior genotypes depends on genetic and environmental parameters for traits of interest, though (Blind et al., 2018).

Coefficients of experimental variation ranged from $5.09 \%$, for number of days for fruit maturation (NDM) to $44.87 \%$, for number of fruits per plant (NFP). This coefficient, relatively high, may be associated with the germplasm used in this study, since this genetic material is still in process of pre-breeding, presenting unevenness in the number of fruits, even within the same accession.

All evaluated traits showed higher values of genetic variance when compared with values for environmental variance, showing predominance of genetic effects over environmental effects. The values of coefficient of genetic variation and experimental coefficient of variation ratios $[\mathrm{Cvg} /$ Cve(\%)] ranged from $1.59 \%$ for NDM to $5.79 \%$ for LDF. Values higher than or equal to the unit showed the existence of great genetic variability to be used in breeding (Cruz et al., 2014).
The evaluated traits indicated high values for coefficient to genotypic determination coefficient, which ranged from $89.95 \%$ for PSF to $99.26 \%$ for LDF. Thus, the phenotypic values of these treatments have high correlation with genotypic values, which means, the studied germplasm showed heritable phenotypic variability. Moreira et al. (2015), working with inbred lines of C. annuum, found similar values for coefficient of genotypic determination $\left(\mathrm{H}^{2}\right)$ ranging above 82.29 for fruitrelated traits.

Considering the nine evaluated variables, the diagnosis of multicollinearity showed $\mathrm{NC}=$ 432.80 , indicating a moderate to strong collinearity. In order to deal with this strong multicollinearity, first, the authors used the methodology proposed by Carvalho et al. (1999), called Crest Path Analysis, where a constant (k) was added to the diagonal elements of the $X^{\prime} X$ matrix. However, this methodology was not efficient to reduce the multicollinearity. Hence, the authors excluded the variables. To choose the variables to be discarded, we observed the ones which presented high correlation among themselves. So, we excluded ADP (plant height) and

Table 1. Accessions of Capsicum annuum, their respective collection sites and traits. Teresina, UFPI, 2017.

\begin{tabular}{lccc}
\hline BAGC & Common name & State & Average height (cm) \\
\hline 236 & "Pimenta-de-mesa" & Piaúi & 20.75 \\
98 & Ornamental orange pepper & Piauí & 20 \\
224 & Ornamental red pepper & Maranhão & 23 \\
199 & Ornamental purple pepper & Ceará & 20.75 \\
207 & Ornamental yellow pepper & Ceará & 21.5 \\
228 & Yellow-sweet pepper & Ceará & 21.75 \\
180 & Red bell pepper & Rio Grande do Norte & 42.5 \\
150 & Not identified & Pernambuco & 40.5 \\
202 & Long Cayenne & Paraíba & 49 \\
203 & "Pimenta-de-mesa" & Paraíba & 45.5 \\
220 & Red pepper & Paraíba & 18.25 \\
229 & Jalapeño & Paraíba & 36.25 \\
230 & Cayenne pepper & Paraíba & 33.5 \\
149 & Yellow bell pepper & Alagoas & 40.25 \\
145 & Sweet pepper & Sergipe & 41.5 \\
148 & Red bell pepper & Sergipe & 31 \\
\hline
\end{tabular}


PDF (fruit weight). After discarding these two variables, a new diagnosis of multicollinearity was performed, in which $\mathrm{NC}$ was 48.82 , finalizing matrix adjustment.

The authors observed positive and significant genotypic correlation (0.5037) between NDF x NDM and negative correlation for NDF x PSF (-0.5263) (Table 2). These correlations are important in ornamental peppers, as the shorter the period of days for flowering, for maturation and greater persistence of fruits in plants, the more interesting and attractive it will be for the consumer.

We verified negative correlations for NFP and CDFol. The values observed for phenotypic and genotypic correlations were -0.4163 and -0.5039 , respectively (Table 2). Thereby, in accessions with shorter leaves, the amount of fruit will be greater. This correlation can be used to shorten the time of breeding programs which aim to work with number of fruits per plant, since the indirect selection can

Table 2. Estimate of phenotypic correlation ( and genotypic correlation coefficients of seven agronomic traits in 16 pepper accessions (Capsicum annuum) with ornamental potential. Teresina, UFPI, 2017.

\begin{tabular}{|c|c|c|c|c|c|c|c|}
\hline Variables & $r$ & $\mathrm{NDM}^{2}$ & NFP $^{3}$ & PSF $^{4}$ & CDF $^{5}$ & $\mathbf{L D F}^{6}$ & $\mathrm{CDFol}^{7}$ \\
\hline \multirow{2}{*}{$\mathrm{NDF}^{1}$} & $r_{f}$ & $0.4628 * *$ & -0.2424 & $-0.5263 * *$ & -0.1434 & 0.1558 & 0.1563 \\
\hline & $r_{g}$ & $0.5037 * *$ & -0.1289 & $-0.6665^{* *}$ & -0.3044 & 0.1121 & 0.3022 \\
\hline \multirow{2}{*}{ NDM } & $r_{f}$ & & -0.2806 & 0.0358 & 0.0863 & 0.0254 & -0.2551 \\
\hline & $r_{g}$ & & $-0.4015^{*}$ & 0.2022 & 0.2622 & 0.0898 & $-0.4197 *$ \\
\hline \multirow{2}{*}{ NFP } & $r_{f}$ & & & 0.1256 & 0.2935 & -0.028 & $-0.4163^{*}$ \\
\hline & $r_{g}$ & & & 0.1832 & $0.3831^{*}$ & 0.0462 & $-0.5039 * *$ \\
\hline \multirow{2}{*}{ PSF } & $r_{f}$ & & & & $-0.4614 * *$ & 0.0197 & $0.3563^{*}$ \\
\hline & $r_{g}$ & & & & $-0.5652 * *$ & -0.0089 & $0.4745^{* *}$ \\
\hline \multirow{2}{*}{ CDF } & $r_{f}$ & & & & & -0.1546 & $0.8162 * *$ \\
\hline & $r_{g}$ & & & & & -0.2186 & $0.8634 * *$ \\
\hline \multirow{2}{*}{ LDF } & $r_{f}$ & & & & & & $0.4577 * *$ \\
\hline & $r_{g}$ & & & & & & $0.4771^{* *}$ \\
\hline
\end{tabular}

**Significant at $1 \%$ and $5 \%$ probability by $\mathrm{F}$ test, respectively; ${ }^{1}$ Number of days for flowering; ${ }^{2} \mathrm{Number}$ of days for maturation; ${ }^{3} \mathrm{Number}$ of fruits per plant; ${ }^{4} \mathrm{Fruit}$ persistence; ${ }^{5}$ Fruit length; ${ }^{6}$ Fruit width; ${ }^{7}$ Leaf width.

Table 3. Estimate of the direct (diagonal in bold) and indirect (off-diagonal) effects of six agronomic traits on the number of fruits per plant in pepper (Capsicum annuum) with ornamental potential. Teresina, UFPI, 2017.

\begin{tabular}{lccccccc}
\hline Variables & $\mathbf{N D F}^{\mathbf{1}}$ & $\mathbf{N D M}^{\mathbf{2}}$ & $\mathbf{P S F}^{3}$ & $\mathbf{C D F}^{4}$ & $\mathbf{L D F}^{\mathbf{5}}$ & $\mathbf{C D F o l}^{\mathbf{6}}$ & Total \\
\hline NDF & $\mathbf{- 0 . 2 9 3 8}$ & -0.1733 & 0.0840 & 0.1306 & -0.0123 & -0.2712 & -0.7042 \\
NDM & -0.2013 & $\mathbf{- 0 . 2 5 3 0}$ & -0.0582 & 0.0213 & -0.0055 & -0.0459 & -0.5427 \\
PSF & 0.2059 & 0.1228 & $\mathbf{0 . 1 1 9 8}$ & -0.1514 & 0.0069 & 0.1724 & 0.4766 \\
CDF & -0.0981 & -0.0137 & 0.0463 & $\mathbf{0 . 3 9 1 2}$ & -0.0138 & -0.5748 & -0.3557 \\
LDF & -0.1403 & -0.0542 & -0.0321 & 0.2090 & $\mathbf{- 0 . 0 2 5 9}$ & -0.4892 & -0.5328 \\
CDFol & -0.1169 & -0.0170 & -0.0303 & 0.3300 & -0.0185 & $\mathbf{- 0 . 6 8 1 4}$ & -0.5344 \\
$\begin{array}{l}\text { Determination } \\
\text { coefficient }\end{array}$ & & & & & & & 0.6401 \\
Effect of residual & & & & & & & \\
variable & & & & & & & 0.5998 \\
\hline
\end{tabular}

${ }^{1}$ Number of days for flowering; ${ }^{2}$ Number of days for maturation; ${ }^{3}$ Fruit persistence; ${ }^{4}$ Fruit length; ${ }^{5}$ Fruit width; ${ }^{6}$ Leaf length. be carried out in vegetative phase.

Using the path analysis, NFP as base variable, the authors observed a high residual effect (0.59) (Table 3 ), showing that the set of variables used in this study does not totally explain the number of fruits in ornamental pepper plants, since the values of the residual exceeded, except CDFol. Thus, the range observed in number of fruits occurred probably due to other traits which were not mentioned in this study, being able to be evaluated in further studies, though.

Low values of coefficient of determination (0.37) and high values of residual variable $(0.79)$ were also obtained by Cabral et al. (2011), using path analysis for number of seeds per plant in beans (Phaseolus vulgaris). Salla et al. (2015) also obtained low values of coefficient of determination (0.12) and high values for residual effect (0.93) studying jabuticaba fruit traits (Plinia cauliflora). Blind et al. (2018) verified that secondary traits, such as average length and fruit circumference and maximum fiber thickness were not effective in determining the variation in number of fruits $\left(R^{2}=0.288\right)$ and fiber production $\left(R^{2}=0.238\right)$ in vegetable loofah (Luffa cylindrica).

Even taking these results into consideration, the explanatory variables should not be totally discarded due to the low direct effect on the main variable. In these cases, the use of selection indexes would be a good alternative to be used in breeding programs. These indexes may provide favorable and simultaneous gains in many traits (Cruz et al., 2014).

Selection indexes of Mulamba \& Mock (1978) and Genotype-Ideotype (Schwarzach, 1972 cited by Wricke \& Weber, 1986) were used in order to identify promising accessions based on vegetative and reproductive traits, simultaneously. Among the studied 16 accessions, the indexes indicated BAGC 236, BAGC 207, BAGC 199, BAGC 98 and BAGC 228 as the most promising materials, changing only the order within each index. This corresponded to a coincidence of 0.92 ordering the accessions according to Spearman's correlation coefficient (Table 4).

The indexes were efficient for indicating earlier accessions, with 
Table 4. Ranking using the Mulamba \& Mock non-parametric selection index (1978) and Genotype-Ideotype distance based on agronomic traits, evaluated in 16 pepper accessions (Capsicum annuum) with ornamental potential from different states. Teresina, UFPI, 2017.

\begin{tabular}{lccccccccc}
\hline Accessions & NDF $^{\mathbf{1}}$ & $\mathbf{N D M}^{\mathbf{2}}$ & $\mathbf{N F P}^{\mathbf{3}}$ & $\mathbf{P S F}^{\mathbf{4}}$ & $\mathbf{C D F}^{\mathbf{5}}$ & $\mathbf{L D F}^{\mathbf{6}}$ & $\mathbf{C D F o l}^{\mathbf{7}}$ & $\mathbf{M M}^{\mathbf{8}}$ & $\mathbf{G I}^{\mathbf{9}}$ \\
\hline BAGC 236 & 44.75 & 102.25 & 81.75 & 89.25 & 1.09 & 0.49 & 1.36 & $1^{\circ}$ & $2^{\circ}$ \\
BAGC 98 & 49.25 & 107.25 & 14.00 & 82.00 & 3.51 & 1.86 & 6.00 & $4^{\circ}$ & $4^{\circ}$ \\
BAGC 224 & 66.00 & 118.25 & 15.00 & 83.00 & 2.95 & 1.87 & 5.36 & $7^{\circ}$ & $6^{\circ}$ \\
BAGC 199 & 61.00 & 107.00 & 27.50 & 90.00 & 2.70 & 1.96 & 3.88 & $3^{\circ}$ & $3^{\circ}$ \\
BAGC 207 & 57.25 & 109.75 & 80.25 & 90.00 & 2.00 & 1.04 & 4.61 & $2^{\circ}$ & $1^{\circ}$ \\
BAGC 228 & 63.50 & 107.00 & 28.50 & 84.00 & 3.51 & 0.82 & 3.81 & $5^{\circ}$ & $5^{\circ}$ \\
BAGC 180 & 70.50 & 108.50 & 7.75 & 79.50 & 15.21 & 3.96 & 12.15 & $9^{\circ}$ & $14^{\circ}$ \\
BAGC 150 & 73.50 & 127.00 & 6.75 & 96.50 & 4.22 & 3.80 & 7.09 & $10^{\circ}$ & $10^{\circ}$ \\
BAGC 202 & 87.25 & 132.50 & 6.75 & 61.00 & 4.70 & 2.64 & 4.57 & $16^{\circ}$ & $16^{\circ}$ \\
BAGC 203 & 74.00 & 119.00 & 21.50 & 68.00 & 11.94 & 2.29 & 8.07 & $11^{\circ}$ & $12^{\circ}$ \\
BAGC 220 & 73.75 & 114.25 & 8.50 & 85.00 & 1.49 & 1.14 & 4.8 & $6^{\circ}$ & $7^{\circ}$ \\
BAGC 229 & 74.50 & 113.75 & 20.00 & 75.00 & 3.88 & 0.54 & 5.97 & $8^{\circ}$ & $8^{\circ}$ \\
BAGC 230 & 71.00 & 131.50 & 4.25 & 74.50 & 3.89 & 2.41 & 6.16 & $13^{\circ}$ & $11^{\circ}$ \\
BAGC149 & 80.75 & 112.00 & 8.50 & 68.00 & 6.13 & 5.35 & 7.88 & $14^{\circ}$ & $13^{\circ}$ \\
BAGC 145 & 85.00 & 131.50 & 4.25 & 64.50 & 4.90 & 1.64 & 4.54 & $15^{\circ}$ & $15^{\circ}$ \\
BAGC 148 & 80.25 & 112.00 & 7.25 & 72.50 & 5.24 & 3.26 & 8.1 & $12^{\circ}$ & $9^{\circ}$ \\
\hline
\end{tabular}

${ }^{1}$ Number of days for flowering; ${ }^{2}$ Number of days for maturation; ${ }^{3}$ Number of fruits per plant; ${ }^{4}$ Fruit persistence; ${ }^{5}$ Fruit length; ${ }^{6}$ Fruit width; ${ }^{7}$ leaf length; ${ }^{8}$ Mulamba \& Mock Index; ${ }^{9}$ Genotype-Ideotype Index.

greater number of fruits per plant and greater fruit persistence. The accessions recommended ranged from 70.5 to 44.75 for NDF and 27.5 to 81.75 for NFP. These accessions produced fruits which persisted up to 90 days in plants (Table 4). This is important since the ornamental value of the peppers is directly related with permanence of the fruits in the plant. The results for NDF are in accordance with the results obtained by Nascimento et al. (2019) working with 6 generations of ornamental pepper plants, which showed values from 38.65 to 95 . Silva et al. (2015) found results similar to these ones in this study, except for one accession which produced 137.3 fruits; these authors also obtained accessions of NDF ranging from 41.7 to 80 . The values of NDF obtained by Nascimento et al. (2019) ranged between 15 and 70 days. The studies cited, as well as the results obtained in this experiment, are within the quality standards for commercialization, $\mathrm{NFP} \geq 10$ (Veilling Holambra, 2018).

We highlight that even the plant height not being used in the selection index, the indicated accessions (BAGC
236, BAGC 207, BAGC 199, BAGC 98 and BAGC 228) presented an average height within the quality standards for commercialization, being 14 to $32 \mathrm{~cm}$, for the pot size used in this experiment (Veilling Holambra, 2018). Therefore, such accessions, which have an average height between 20 and $21.75 \mathrm{~cm}$ (Table 1), are suitable for ornamental purposes and can be used to start crosses in the Ornamental Pepper Breeding Program in the state of Piauí.

\section{ACKNOWLEDGMENTS}

To Coordination of Improvement of Higher Education Personnel (CAPES).

\section{REFERENCES}

ALCÂNTARA, FA; RIBEIRO, CSC. 2008. Solos e adubação: In: RIBEIRO, CSC; LOPES, CA; CARVALHO, SIC; HENZ, GP; REIFSCHNEIDER, FJB (eds). Pimentas Capsicum. Embrapa Hortaliças. p.81-93.

ANDRADE JUNIOR, AS; BASTOS, EA; SILVA, CO; GOMES, AAN; FIGUEREDO JÚNIOR, LGM. 2004. Atlas climatológico do estado do Piauí. Embrapa Meio-Norte. Teresina: Embrapa Meio-Norte. 151p.
BLIND, AD; VALENTE, MSF; LOPES, MTG; RESENDE, MDV. 2018. Estimativa de parâmetros genéticos, análise de trilha e seleção em bucha vegetal para caracteres agronômicos. Revista Brasileira de Ciências Agrárias 13: 1-8.

CABRAL, PDS; SOARES, TCB; LIMA, ABP; SOARES, YJB; SILVA, JA. 2011. Análise de trilha do rendimento de grãos de feijoeiro (Phaseolus vulgaris L.) e seus componentes. Revista Ciência Agronômica 42: 132-138.

CARVALHO, CGP; OLIVEIRA, VR; CRUZ, CD; CASALI, VWD. 1999. Análise de trilha sob multicolinearidade em pimentão. Pesquisa Agropecuária Brasileira 34: 603-613.

COSTA, GN; SILVA, BMP; LOPES, ACA; CARVALHO, LCB; GOMES, RLF. 2019. Selection of pepper accessions with ornamental potential. Revista Caatinga 32: 566-574.

CRUZ, CD. 2013. Genes: a software pakage for analysis in experimental statistics and quantitative genetics. Acta Scientiarum. Agronomy 35: 271-276.

CRUZ, CD; CARNEIRO, PCS; REGAZZI, AJ. 2014. Modelos biométicos aplicados ao melhoramento genético. Viçosa: UFV. 668p.

CRUZ, CD; REGAZZI, AJ; CARNEIRO, PCS. 2012. Modelos biométricos aplicados ao melhoramento genético. Viçosa: UFV. 514p.

FINGER, FL; PEREIRA, MP. 2016. Physiology and postharvest of pepper fruits. In: RÊGO, ER; RÊGO, MM; FINGER, LF (eds). Production and breeding of chili peppers (Capsicum spp.) Springer.

INSTITUTOBRASILEIRODEFLORICULTURA (Ibraflor). Critérios de classificação. Available at $<$ http://www.ibraflor.com/p qualidade. 
php $>$. Accessed January 08, 2020.

I N S T I T U T O B R A S I L E I R O D E FLORICULTURA (Ibraflor). Número do setor. Available at $<$ https: $/ /$ www.ibraflor.com. br/numeros-setor $>$. Accessed August 19, 2020.

INTERNACIONAL PLANT GENETIC RESOURCES INSTITUTE (IPGRI). 1995. Descritores para Capsicum - (Capsicum spp.). Roma. 51p.

LIMA, PCC; RIBEIRO, WS; OLIVEIRA, MMT; COSTA, LC; FINGER, FL. 2017. Ethylene, 1-methylcyclopropene and silver thiosulfate on the post-production of ornamental pepper. Ciência Rural 47: 1-8.

MONTEIRO, ER; BASTOS, EM; LOPES, ACA; GOMES, RLF; NUNES, JAR. 2010. Diversidade genética entre acessos de espécies cultivadas de pimentas. Ciência Rural 40: 288-283.

MOREIRA, SO; KUHLCAMP, KT; BARROS, FLS; OLIVEIRA, SB; TRINDADE, RS. 2018. Path analysis under multicollinearity for papaya production of the Solo and Formosa group. Revista Brasileira de Fruticultura 40: 1-10.

MOREIRA, SO; RODRIGUES, R; ARAÚJO, ML; SUDRÉ, CP; RIVA-SOUZA, EM. 2015. Resistência à mancha-bacteriana e características agronômicas de linhas recombinadas de Capsicum annuum L. Revista Brasileira de Ciências Agrárias 10: 198-204.

MULAMBA, NN; MOCK, JJ. 1978. Improvement of yield potential of the Eto Blanco maize
(Zea mays L.) population by breeding for plant traits. Egyptian Journal of Genetics and Cytology 7: 40-51.

NA S CIMENTO, MF ; R ÊGO, ER; NASCIMENTO, NFF; LEITE, PSS; FINGER, FL; BRUCKNER, CH; RÊGO, MM. 2019. Heritability of morpho-agronomic traits in ornamental pepper. Crop Breeding and Applied Biotechnology 19: 253-261.

RAMALHO, MAP; ABREU AFB; SANTOS JB; NUNES JAR. 2012. Aplicações da genética quantitativa no melhoramento de plantas autógamas. Lavras: UFLA. 522p.

RANGEL, RM; AMARAL JÚNIOR, ATD; JÚNIOR F; PAIVA, S. 2011. Associação entre características agronômicas e capacidade de expansão em população de milho pipoca sob seleção recorrente. Ciência e Agrotecnologia 35: 225-233.

RÊGO, ER; RÊGO, MM. 2016. Genetics and breeding of chilli pepper Capsicum spp. In: RÊGO, ER; RÊGO, MM; FINGER, FL (eds). Production and breeding of chilli peppers (Capsicum spp.). Springer International Publishing, Cham. p.1-129.

RÊGO, ER; RÊGO, MM. Ornamental pepper. In: Ornamental crops. Springer, Cham, 2018. p.529-565.

RIBEIRO, WS; CARNEIRO, CDS; FRANÇA, CDFM. PINTO, CMF; LIMA, PCC; FINGER, FL; COSTA, FB. 2019. Sensitivity of ornamental pepper to ethylene. Horticultura Brasileira 37: 458-463.
SALLA, VP; DANNER, MA; CITADIN, I; SASSO, SAZ; DONAZZOLO, J; GIL, BV. 2015. Análise de trilha em caracteres de frutos de jabuticabeira. Pesquisa Agropecuária Brasileira 50: 218-223.

SANTOS, HG; CARVALHO JUNIOR, W; DART, RO; AGLIO, MLD; SOUSA, JS; PARES, JG; FONTANA, A; MARTINS, ALS; OLIVEIRA, AP. 2011. Mapa de solos do Brasil (pdf). Embrapa solos núcleo de geométricas (NGEO) Embrapa Solos. Available at $67 \mathrm{http}: / /$ mapoteca.cnps.embrapa.br/download/obj/ ok1754.pdf Accessed May 09, 2015.

SILVA, CQ; JASMIM, JM; SANTOS, JO; BENTO, CS; SUDRÉ, CP; RODRIGUES, R. 2015. Phenotyping and selecting parents for ornamental purposes in chili pepper accessions. Horticultura brasileira 33: 66-73.

SPEARMAN, C. 1904. The proof and measurement of association between two things. The American Journal of Psychology 1:72-101.

VEILING HOLAMBRA. 2018. Critérios de classificação pimenta ornamental. Available at $<$ http://veiling.com.br/uploads/padrao qualidade/criterios/pimenta-ornamental-po. pdf $>$. Accessed August 21, 2019.

WRICKE, G; WEBER, WE. 1986. Quantitative genetics and selection in plant breeding. Walter de Gruyter, NY. 406p.

WRIGHT, S. 1921. Correlation and causation. Journal of Agricultural Research 20: 557-585. 